\section{BOTANY AS A NEW FIELD OF KNOWLEDGE IN THE THIRTEENTH CENTURY: ON THE GENESIS OF THE SPECIALIZED SCIENCES}

\begin{abstract}
The reception of the translations of Aristotelian and pseudo-Aristotelian works at the University of Paris in the thirteenth century promoted a new understanding of the sciences as specialized fields of knowledge. The huge amount of translations required a new organization of knowledge, which included novel subjects and categories. Among these there is a very special case, namely the pseudoAristotelian De plantis, translated from Arabic into Latin and then back into Greek to be re-translated into Latin again. De plantis was included in the new curriculum in Ripoll 109 (1230-1240 BCE), and constituted the main source for botanical studies until the sixteenth century. Throughout this paper we will explore the reception and impact of De plantis in both the Arabic and the Latin traditions. We aim to show its foundational role in the development of botany as a theoretical discipline within the natural sciences.
\end{abstract}

Keywords: botany; De plantis; Aristotle; Nicolaus Damascenus; Kitab al-Nabat

\section{MUSTAFA YAVUZ}

History of Science Department Istanbul Medeniyet University Karayolu 98, 34720 Istanbul, Turkey email / mustafay007@gmail.com (iD) 0000-0002-7797-8459

\section{Botanika jako nový obor ve 13. století: $O$ vzniku speciálních věd}

Abstrakt: Recepce překladů aristotelských (včetně pseudo-aristotelských) textů na Pařižské univerzitě 13. století širíla nové porozumění vědám jakožto specializovaným oblastem poznání. Velké množství překladì vyžadovalo novou reorganizaci vědění, která musela zahrnout nové predměty a kategorie. Mezi těmito překlady můžeme najít velmi specifický prípad - pseudo-aristotelský spis De plantis, př́eložený $z$ arabštiny do latiny, poté zpèt do řčctiny a nakonec znovu preložený do latiny. De plantis byl zahrnut do nového kurikula v Ripollu 109 (1230-1240 n.l.) a tvořil hlavní pramen pro botanické studie až do 16. století. V tomto článku zkoumáme prijetí a dopad De plantis jak na arabskou, tak na latinskou tradici. Našim cílem je ukázat jeho fundamentální roli ve vývoji botaniky jako nové disciplíny v rámci prírodních věd.

Klíčová slova: botanika; De plantis; Aristoteles; Mikulášz Damašku; Kitab al-Nabat

\section{PILAR HERRAIZ OLIVA}

History of Science Department Istanbul Medeniyet University Karayolu 98, 34720 Istanbul, Turkey email / piliherraiz@gmail.com

(iD) 0000-0001-5365-8613

(c) (P) This work is licenced under the Creative Commons Attribution 4.0 International License. 


\section{Introduction}

In contemporary biology, botany as a term denotes the science of plants and also the biology of plants. It should also be said that botany deals not only with plants, but also with any biological organism consisting of plant cells, and, in this regard, anything dealing with phytology is also studied under botany. In fact, the twin terms botany and phytology are often used interchangeably. However, if we examine the etymology and the ancient uses of these two terms, we can conclude that there is a slight difference between them: botany is derived from Ancient Greek $\beta o \tau \alpha v \eta$ meaning "grass, fodder" or "grassland." The equivalent Latin term is herba, i.e., "herb." Yet the etymology of phytology has to be traced back to $\varphi v \tau o v$, meaning "that which has grown, sprout", and its Latin equivalent is planta. ${ }^{2}$ The Arabic term used for plants in general is "نبات nabat," which exactly covers the conceptual background as it is in $\varphi v \tau o v$ of Ancient Greek. In Arabic, the root نبت (n·b·t) denotes the action "to shoot, to bud, to sprout from the ground" while in Turkish, the words bitmek, as a verb, and bitki, as a noun, have the same meaning. These words are translated into English as "to plant," as a verb, or "plant" as a noun. Both correspond to the Greek $\varphi v \tau o v$.

Botany and zoology are the oldest branches of biology. In contemporary biology, biologists tend to coin new terms or combinations by using words selected from Ancient Greek or Medieval Latin. When creating new functional terms, most roots for new words come from Greek, whereas the prefixes or suffixes are usually taken from Latin. Thus, in contemporary botany, we can identify and trace the borrowed words in the chain of terminology from Ancient Greek to Medieval Arabic, from Arabic to Medieval Latin, and from Latin to the present-day terminology. Nevertheless, since in some cases Medieval Arabic precedes Medieval Latin and, at the same time, this has Ancient Greek as its antecedent, Arabic should also be taken into consideration when coining or translating the botanical terminology.

\section{Importance of Plants in Human Life}

Plants, as a great kingdom of living things and a sine qua non part of global biodiversity, are of great importance in our daily life. In other words, plants are relevant today as they have been important throughout human history.

\footnotetext{
${ }^{1}$ Henry G. Liddell and Robert Scott, Greek-English Lexicon (New York: Harper \& Brothers, 1883), 289.

${ }^{2}$ Ibid., 1702.
} 
A very popular book about the history of civilization and evolution ${ }^{3}$ discusses and exemplifies how plants changed the fates of human societies. To name a few, the practical uses of plants in history include cosmetics, food, fuel, medicine, poison, protection, shelter and others. These samples indicate that plants have been important for humankind from the very beginning and, consequently, that the knowledge pertaining to plants or the uses of plants has been crucial for humanity as well. We can conclude that humankind used plants to survive and to live.

According to the data of contemporary botany, the kingdom of plants covers almost $20 \%$ of the total biodiversity in the biosphere ${ }^{4}$ and occupies the maximum amount of biomass, $81 \%$ of the total on Earth. So, when we consider how much of the biodiversity of the planet consists of plants, we can easily see why they are important in our daily routines, in which plants occupy a bigger space than animals do. This is why humans (have to) use plants more than any other living or non-living things in their practices. In order to achieve sustainable uses of plants and to pursue long-lasting benefits from them, two activities have been primarily performed by humans: one is growing plants to harvest plant products; the other is the identification of plants to distinguish plant species from one another. The daily practices on plants may be regarded as a tekhne type of knowledge, which may develop into theoretical information over time, or an episteme type of knowledge.

According to our understanding and definition of "science" we can trace the history of botany as a "plant science" back to Nicolaus Cusanus (1450), who was famous for his studies in plant physiology before the eminent figures in the sixteenth century, which is also regarded as a prolific period in the Western world. ${ }^{5}$ In the sixteenth century there were two main streams

${ }^{3}$ Jared Diamond, Guns, Germs, and Steel: The Fates of Human Societies (New York: Norton, 2005), 104-13. Starting from the sixth chapter of his book, Diamond describes how huntergatherer human societies evolved into food producers - in the fertile crescent due to geographical circumstances - thus attaining a longer expected lifetime with less physical work and more comfort, as compared to their past.

${ }^{4}$ According to the Catalogue of Life 2018, Regnum Plantae has 366,474 species among the total biodiversity of $1,834,340$. Besides these numbers indicating the situation in biodiversity, a recent study, Yinon M. Bar-On, Rob Phillips, and Ron Milo, “The Biomass Distribution on Earth," PNAS 115, no. 25 (2018): 6506-11, estimates the biomass distribution on Earth. The researchers establish a census of $\approx 550$ gigatons of carbon (Gt C) of biomass distributed among all the kingdoms of life, where plants occupy $\approx 450 \mathrm{Gt}$ C.

5 "Botany as a science," or the scientific study of plants, can also start with the works of Theophrastus since his Historia Plantarum is full of examples of plant parts, plant products, human intervention and operations on plants, etc. 
in botanical studies: one focusing on translations and annotations of the Dioscoridean De materia medica, especially in Italian and Spanish (e.g., P. A. Matthioli, d. 1577, and Andrés Laguna, d. 1559), the other one in Northern Europe focusing on new herbals, minute observations and accurate illustrations of plants, especially in German (e.g., Leonhardt Fuchs, d. 1566). Books on materia medica are not included in the topic of this paper. The sixteenth century also yielded many books authored by Western travelers and scholars, such as accounts of travels to foreign countries, especially to the Ottoman Lands. However, these are not part of our topic either, since we have limited space.

Throughout this paper, we will question the historiographical tradition and challenge these views on the origins of botany as a science. For indeed, the binomial nomenclature of plants started with Dioscorides (BCE $1^{\text {st }}$ century) and it was already developed in the Arabic texts of Islamic scholars in medieval times. In addition, as we will show in the second part of this paper, the bases for the development of botany as a science can also be traced back to the thirteenth century in its Latin counterpart. Consequently, in this article, we aim to look at botanical works dating from before the thirteenth century and their impact on the shaping of botany as a science. Firstly, we will do so in the medieval Islamic civilization, where the language of science was Arabic. Secondly, we will turn to the reception of the Graeco-Arabic material in the Latin West and its importance for the understanding of botany as a specialised science.

\section{The Arabic Tradition and Transition of Botanical Knowledge}

As one of the authors of this paper has shown in an earlier study, ${ }^{6}$ we can classify the genre of works about plants given in the Islamic geography as indicated in table 1 . The names of authors in this table are selected from among those who are well-known until our times, indeed a different approach may result in a different table. However, the table given here is similar to the one prepared for works in antiquity. This table also summarizes the data about plants as related to the needs of welfare in a society: nutrients, knowledge

\footnotetext{
${ }^{6}$ We have proposed a very similar classification in one of our previous works still in print: Mustafa Yavuz and Özlem Korkmaz, "Botánica en al-Ándalus: un estudio comparativo de trabajos ilustrados de botánica en el Magreb y Máshreq," Awraq, no. 17-18 (2017): 169-86.

${ }^{7}$ In their inspiring work, Frederick Gavin Hardy and Laurence M. V. Totelin give an idea on the classification of botanical works to their subject or purpose. See Frederick Gavin Hardy and Laurence M. V. Totelin, Ancient Botany (London: Routledge, 2016), 1-32.
} 
or science of plants, and health issues. According to the last column in the table, the requirement for knowledge or science was supplied by natural philosophy. This topic was discussed in books named Kitab al-Nabat, i.e., Book on Plants. Aristotle and Theophrastus were the key figures and, after the translation period, starting from tenth century in the Islamic world, there are many authentic works by several authors, almost all of them written by Peripatetics (meshshai tradition). The opera given in this column mainly discuss the epistemology and ontology of phenomena related to plants.

\begin{tabular}{|c|c|c|c|}
\hline Requirement & Nutrient & Health & Knowledge / Science \\
\hline Procurement & Agriculture & Pharmaco-Medicine & Philosophy \\
\hline Kitab al-... & Filaha & $\begin{array}{l}\text { Adwiyyat } \\
\text { al-Mufradah }\end{array}$ & Nabat \\
\hline Pioneer & Cassianus Bassus & Dioscorides & $\begin{array}{l}\text { Aristoteles- } \\
\text { Theophrastus }\end{array}$ \\
\hline $9^{\text {th }}$ Century & -- & $\begin{array}{l}\text { Hunayn ibn Ishaq } \\
\text { Ali Ibn Rabban } \\
\text { al-Tabari }\end{array}$ & -- \\
\hline $10^{\text {th }}$ Century & Ibn Wahshiyya & $\begin{array}{l}\text { Ibn Zakariya al-Razi } \\
\text { Ali ibn Abbas } \\
\text { al-Majusi } \\
\text { Ibn Juljul }\end{array}$ & $\begin{array}{l}\text { Ikhwan al-Safa } \\
\text { Ibn Juljul }\end{array}$ \\
\hline $11^{\text {th }}$ Century & $\begin{array}{l}\text { Ibn Hajjaj al-Ishbili } \\
\text { Abu al-Khayr } \\
\text { al-Ishbili } \\
\text { Ibn Bassal }\end{array}$ & $\begin{array}{l}\text { Ibn Wafid } \\
\text { Ibn al-Jazzar } \\
\text { Ibn Sina } \\
\text { Biruni }\end{array}$ & $\begin{array}{l}\text { Abu Hanifa } \\
\text { Dinawari } \\
\text { Ibn Sina } \\
\text { Abu al Faraj ibn } \\
\text { al-Tayyib } \\
\end{array}$ \\
\hline $12^{\text {th }}$ Century & -- & $\begin{array}{l}\text { Zahrawi } \\
\text { Idrisi } \\
\text { Abu Jafar al-Ghafiqi }\end{array}$ & $\begin{array}{l}\text { Ibn Bajja } \\
\text { Ibn Rushd }\end{array}$ \\
\hline $13^{\text {th }}$ Century & $\begin{array}{l}\text { Ibn Yahya al-Watwat } \\
\text { Ibn al-Raqqam }\end{array}$ & Ibn al-Baitar & -- \\
\hline
\end{tabular}

Table 1. Types of Botanical Sources in Islamic Science

Texts written by ancient Greek philosophers were translated into Arabic and then commented on by Islamic philosophers, who also composed original works or added their local observations. They also accepted the Empe- 
doclean four elements (Earth, Air, Fire, Water), together with the subsequent four qualities and the status of plants as living beings.

The Islamic philosophers' sources can be traced not only to Aristotle, but also to Plato, who also distinguished between plants, animals, and humans. ${ }^{8}$ Moreover, his tripartite explanation on vitality (the appetitive soul, the spirited soul and the rational soul) was also inspiring for them. In the Timaeus, Plato asserts that "plants seek desire and pleasure, and they avoid pain." Since plants are sessile, they grow to supply animals and, consequently, humans. ${ }^{9}$ This teleological explanation fits with the anthropocentric view, asserting humans as superior organisms.

According to the main trends in recent scholarship, and following the Ancient Greek tradition, Islamic scholars in the medieval period accepted the idea of discriminating between biological organisms depending on the theory of soul. Such discrimination was possible by means of several actions such as nutrition, growth, reproduction, and types of motion. ${ }^{10}$ Thus, as shown in table 2, in Islamic natural philosophy, the main difference between plants and animals was that of voluntary motion (الحركات الإرادية), whereas animals and humans were to be distinguished by optional motion (الاختباركاتة

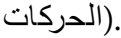

\begin{tabular}{|l|c|c|c|}
\hline & Plants & Animals & Humans \\
\hline Nutrition & $\mathrm{X}$ & $\mathrm{X}$ & $\mathrm{X}$ \\
\hline Growth & $\mathrm{X}$ & $\mathrm{X}$ & $\mathrm{X}$ \\
\hline Reproduction & $\mathrm{X}$ & $\mathrm{X}$ & $\mathrm{X}$ \\
\hline Voluntary Motion & & $\mathrm{X}$ & $\mathrm{X}$ \\
\hline Optional Motion & & & $\mathrm{X}$ \\
\hline
\end{tabular}

Table 2. Types of Organisms

But for this discrimination, philosophers in the Islamic world needed curricular sources, i.e., books, differentiated by their titles and their contents, such as Kitab al-Nabat (Book on Plants) and Kitab al-Hayawan (Book on Animals). These were extant at least in a commentary by Ibn Sina (d. 1037), together with the texts received from the Ancient Greek legacy. In this study

\footnotetext{
${ }^{8}$ Plato, Republic IV 431c.

${ }^{9}$ Plato, Timaeus $77 \mathrm{~b}-\mathrm{c}$.

${ }^{10}$ As derived from Ibn Sina's Kitab al-Shifa, al-Isarat wa al-Tanbihat, Namat 3.
} 
we focus on one of Ibn Sina's sources on plants, Kitab al-Nabat (De plantis), and its Greek counterpart by Nicolaus of Damascus.

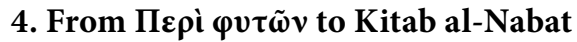

The Book on Plants ( $\Pi \varepsilon \rho i$ i $\varphi v \tau \tilde{\omega} v$, De plantis) is a work initially attributed to Aristotle, although it is nowadays generally believed to have been authored by Nicolaus of Damascus, who wrote it in the first century BCE. This text, which is actually a commentary on a work of Aristotle, is not preserved in the original Greek, although, as we will see, there are retro-translations from Latin into Greek. An Arabic translation is extant in some manuscripts, separately, and also inserted in a commentary of Ibn Sina. The Latin translations were famous and widespread in Europe, as it will be discussed below.

There is an Arabic translation of Nicolaus's work made by Ishaq ibn Hunain, and corrected by Thabit ibn Qurra. The first codex ${ }^{11}$ was provided with a modern introduction, ${ }^{12}$ edited twice ${ }^{13}$ and translated into English ${ }^{14}$ in the twentieth century. Several questions arise on the identity and authenticity of the text and on the date of the codex. Fuat Sezgin ${ }^{15}$ mentions this codex as the oldest one, dating it back to eighth century (AH). However, in the last page of the compiled book, we find that it belongs to at least $679^{16} \mathrm{AH}$, and thus 1280-1281 CE (fig. 1).

According to the relevant literature, this is the oldest extant text of Nicolaus in Arabic. In the introductory page there is a marginal inscription in Ottoman Turkish. There is no date, but it should be dated before 1924, when the Latin alphabet started being used in Turkey. It says: "This book is

\footnotetext{
${ }^{11}$ This codex is at Yeni Cami Collection No: 1179, Suleymaniye Manuscript Libray, Istanbul, Turkey.

${ }^{12}$ Introduction of the Arabic De plantis to scientific knowledge by Maurice Bouyges, "Sur le de Plantis d' Aristote-Nicolas à propos d'un manuscrit arabe de Constantinople," Mélanges de L'Université Saint-Joseph Beyrouth 9, no. 2 (1923): 71-89.

${ }^{13}$ Arthur J. Arberry, "An Early Translation from the Greek," Bulletin of the Faculty of Arts of the Cairo University 1 (1933): 48-76, and Abdarrahman Badawi, Aristatalis fi n-nafs (Cairo: Maktabat al-Nahdah al-Misriyyah, 1954) give editions of the Arabic text.

${ }^{14}$ Hendrik J. Drossaart Lulofs and Evert L. J. Poortman provide an English translation of Arabic text between pages 115-215 in Nicolaus Damascenus, De plantis. Five Translations, eds. Hendrik J. Drossaart Lulofs and Evert L. J. Poortman (Amsterdam: North-Holland Publishing, 1989).

${ }^{15}$ Fuat Sezgin, GAS IV, 313.

و ستما للهجرة.. In the final line of this Arabic inscription, which is a birth record, we can read 679 AH.
} 
authored by Theophrastus, a student of Aristoteles. Later it was attributed to Aristo" (fig. 2).

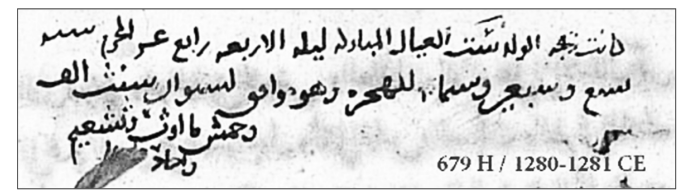

Figure 1. Date at folio $490^{\mathrm{b}}$

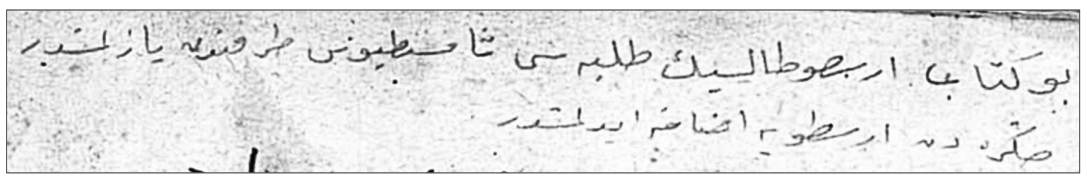

Figure 2. Marginal note at Folio $97^{\mathrm{a}}$

The first page of the text obviously informs us about the identity of the text. With a rough translation, it can be read as: "In the name of Allah, the Most Gracious, the Most Merciful. My Lord, make it easy (for me). Book of Aristoteles on Plants, Commentary of Nicolaus, Translation of Ishaq ibn Hunain, Correction of Thabit ibn Qurra. It is two articles. Aristoteles the philosopher said that: 'Definitely life exists in animals and in plants. However, the life of animals is manifest and clear whereas the life of plants is hidden and concealed."'17

The text describes the nature and origins of plants, compares the parts of plants, etc. in two books. The first book consists of topics such as the nature of plant life, the sexes and parts of plants; the structure and classification of plants; the composition and products of plants, methods of propagation and fertilisation, and changes and variations in plants. The second book focuses on the origins of plant life: "concoction" and its variations in the earth and the sea; the matter of plants; the effects of outward conditions and climate,

${ }^{17}$ The original Arabic text is as follows:

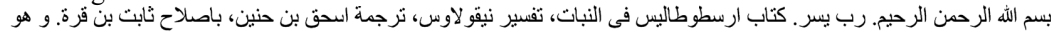
مقالتان. فال الفيلسوف ارسطوطاليس: ان الهياً موجودة فى الحيو ان و النبات؛ غير ان حياة الحيو ان بينة ظاهرة، و حياة النبات خفية غامضة. 
aquatic plants, saxicolous plants, other effects of locality on plants; parasitism, the production of fruits and leaves, the colors and shapes of plants, and finally fruits and their flavour.

As for Ibn Sina's commentary, it has been said ${ }^{18}$ that Ibn Sina ignored the second book of Nicolaus. However, in his marvelous volume Kitab al-Šifa (كتاب الثفاء, sufficientia), Ibn Sina has a book named Auscultation of Nature, ${ }^{19}$ which is briefly known as Book of Nature. Under that title, he includes the Kitab al-Nabat (Book of Plants) as the $7^{\text {th }}$ Fen. It is only one article consisting of seven chapters, unlike Nicolaus's De plantis, comprised of two articles. ${ }^{20}$ In his commentary named Kitab al-Nabat, Ibn Sina calls those seven chapters "fasl" (section, chapter), and they are organized as follows: the first Fasl focuses on the genesis of plants, their nutrition, their sexes and their characteristics; the second Fasl on the parts of plants; the third, on the principles of nutrition, sexual and asexual reproduction; the fourth Fasl on the aspects of generation of plant parts; the fifth defines some of the aspects of transportation of plants, branches and leaves; the sixth Fasl deals with the generation of plants from fruits and seeds, and the seventh with general issues regarding the classification of plants. ${ }^{21}$ It is obvious that he read both books (better to say articles) contained in Kitab al-Nabat (an Arabic version of Nicolaus's De plantis) but combined them or made a new synthesis of them, changing the arrangement of topics in the text. Ibn Sina also added chapter titles in his work.

The echoes of this treatise would resonate more strongly in the medieval Latin West after the translation movement took place between the twelfth and thirteenth centuries. The rediscovery of Aristotelian philosophy as a whole would not be limited to the works of Aristotle, but it would include other works, such as pseudo-Aristotelian treatises, as it is the case here, together with works by philosophers from the Islamic geography. This is what we call the Graeco-Arabic legacy. Within the next section, we will describe the reception of the Book on Plants within the larger context of the rediscovery of the Graeco-Arabic legacy and its role in making botany a specialized field of knowledge. Whereas most of the previous works on plants were dedicated to

\footnotetext{
${ }^{18}$ Drossaart Lulofs \& Poortman, Five Translations, 115-215.

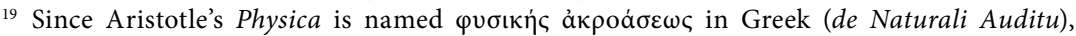
probably Ibn Sina - in an allusion - named his book السماع الطبيعي which can be translated as "what has been heard concerning nature," or briefly Auscultation of Nature.

الفن السابع. في النبات من جملة الطبيعيات. وهو مقالة واحدة تشتمل على سبعة فصدول. Ha gives the title as

${ }^{21}$ These titles are translated by the first author of this article from Ibrahim Bayyumi Madkur, Ibn Sina al-Shifa, al-Tabiiyyat (Cairo: Dar al-Katib al-Arabi li-al-Tibaa wa-al-Našr, 1969).
} 
human usage in fields like agriculture, medicine and pharmacy, this treatise would inaugurate a theoretical tradition in botany, which is more a science than an art when compared to the disciplines mentioned above.

\section{The Latin Tradition ${ }^{22}$}

After the reception of Aristotelian works in translation in the twelfth and thirteenth centuries, the notion of knowledge, along with philosophy as a discipline, underwent a substantial change in the Latin West. The rediscovery of the Graeco-Arabic legacy also affected the understanding of concepts such as nature and, subsequently, it also influenced the view of what the object of natural philosophy was. These changes resulted in the gradual abandonment of the trivium and the quadrivium, which would no longer be placed at the center of the curriculum of studies. The renewed understanding of natural philosophy would also affect the different disciplines, which would progressively embark upon a process of specialization and secularization. In this section, we will explain the various processes which led towards the specialisation of botanical studies as a theoretical discipline in the late Middle Ages, all within the larger picture of natural philosophy.

In order to show the changes in the conception of philosophical knowledge and the transition to the Aristotelian paradigm in regard to the natural sciences and botanical studies in particular, we will first discuss the classification of knowledge found in Hugh of Saint Victor's Didascalicon (ca. 1130) and Dominicus Gundissalvus's De divisione philosophiae (ca. 1150). In doing this, we will not only focus on the understanding of philosophy but will also draw attention to the definitions of nature (natura) and physics (physica), since they constitute one of the keys to show the development of natural philosophy. Secondly, we will deal with a guide to the study of the arts dating from 1230-1240 belonging to a Parisian Arts Master in order to fully appreciate the progressive displacement of the trivium and the quadrivium in the curriculum. Even though they were not completely left out of the picture, their places changed substantially, from being the central focus of studies to being something peripheral. We will also show that this was the case by

\footnotetext{
${ }^{22}$ The research for this section of the paper was possible thanks to a postdoctoral fellowship granted by TÜBİTAK, the Scientific and Technological Research Council of Turkey, and was carried out at Istanbul Medeniyet University by the second author of this paper. This research was monitored by the first author of this paper.
} 
examining the full curriculum of the University of Paris, whose statute was fully established in 1255, this time containing a purely Aristotelian program of studies.

Here we use Aristotelian rather than Aristotle when referring to both the works and the curriculum. This is because a considerable amount of commentaries elaborated by philosophers from the Islamic world, as well as other works - including pseudo-Aristotelian treatises - were translated into Latin in addition to the Aristotelian corpus. ${ }^{23}$ This will also help us fully appreciate the substantial change that took place in the understanding of the different disciplines following the rediscovery of the Graeco-Arabic material in the Latin West. Given the aim of this article, we will focus on its impact on botanical studies, for which the key text within this context was the Book on Plants, Liber de plantis. The last part of the article will be then devoted to showing its importance in the shaping of a more theoretical perspective for botany as a discipline.

\section{Preliminary Steps Towards the Inclusion of Botanical Knowledge in the Curriculum}

Hugh of Saint Victor's Didascalicon sive De studio legendi is used here as an example of a guide to the study of the Arts prior to the reception of the Aristotelian works. In the aforementioned work, philosophy is described as a discipline which also incorporates the mechanical arts, including medicine and agriculture. It is only in these two areas that plants are mentioned in this treatise, in which the mechanical arts are regarded as a part of philosophy as far as they belong to human actions and entail a type of knowledge. ${ }^{24}$ The

${ }^{23}$ A full list of the different translations and translators, together with their dates of composition, can be found in Bernard G. Dod, "Aristoteles Latinus," in The Cambridge History of Later Medieval Philosophy, eds. Norman Kretzmann, Anthony Kenny, and Jan Pinborg (Cambridge: Cambridge University Press, 2008), 45-79.

24 "De ordine et modo legendi et disciplina. Philosophia dividitur in theoricam, practicam, mechanicam, logicam. theorica dividitur in theologiam, physicam, mathematicam. mathematica dividitur in arithmeticam, musicam, geometriam, astronomiam. Practica dividitur in solitariam, privatam, publicam. Mechanica dividitur in lanificium, armaturam, navigationem, agriculturam, venationem, medicinam, theatricam. Logica dividitur in grammaticam, dissertivam. dissertiva dividitur in demonstrationem, probabilem, sophisticam. probabilis dividitur in dialecticam, rhetoricam. In hac divisione solummodo divisivae partes philosophiae continentur. sunt aliae adhuc subdivisiones istarum partium, sed istae nunc sufficere possunt." Hugo Sancti Victoris, Didascalicon III, 1 [765B]. English translation: "Philosophy is divided into the theoretical, the practical, the mechanical, and the 
division of philosophy in the Didascalicon appears as follows: philosophy is divided into theoretical, practical, mechanical, and logical. Theoretical philosophy includes theology, natural philosophy or rather physica, and mathematics (with elements of the quadrivium, i.e., arithmetic, music, geometry, and astronomy); $;{ }^{25}$ practical philosophy is divided into solitary, private, and public; mechanical philosophy is divided into fabric making, armament, commerce, agriculture, hunting, medicine, and theatrics; and finally, logical philosophy divides into grammar and argument.

The understanding of physica and nature, as they appear in this work, also serve as an example of the changes that the different disciplines underwent in the twelfth and thirteenth centuries, that is, the era that witnessed the rise of the universities. In this respect, physica is defined as the investigation of the causes of things by means of their effects and the investigation of the effects by means of the causes. ${ }^{26}$ As for natura, i.e., nature, there are three possible definitions in the Didascalicon. One refers to nature as an archetype in the divine mind, and then nature is that which gives its being to each thing; the second meaning concerns the particularities of each thing; and the third definition has to do with the power of nature as the maker of perceptible objects. ${ }^{27}$

The Chartrean masters, William of Conches and Thierry of Chartres, together with al-Fārābī's Enumeration of the Sciences among other sources, would inspire Dominicus Gundissalinus's De divisione philosophiae. ${ }^{28}$

logical. The theoretical [part] is divided into theology, physics, and mathematics; mathematics is divided into arithmetic, music, geometry, and astronomy. The practical [part] is divided into solitary, private, and public. The mechanical [part] is divided into fabric making, armament, commerce, agriculture, hunting, medicine, and theatrics. Logic is divided into grammar and argument: argument is divided into demonstration, probable argument, and sophistic: probable argument is divided into dialectic and rhetoric. In this division only the divisive parts of philosophy are contained; there are still other subdivisions of such parts, but those given may suffice for now." We have modified the translation offered by Jerome Taylor in The Didascalicon of Hugh of Saint Victor (New York: Columbia University Press, 1961), 83.

${ }^{25}$ The use of the word physics can be problematic in this context, given its historical meaning. Physica here should be rather understood as natural philosophy, with its many branches developing in time, which would later come to include metaphysics as well.

26 "Physica causas rerum in effectibus suis et effectus a causis suis investigando considerat." Hugo Sancti Victoris, Didascalicon, I, 16, 757D.

${ }^{27}$ Ibid., I, 10.

${ }^{28}$ The sources of Gundissalinus's De divisione philosophiae are also to be found in Boethius and Isidore of Seville - as a Latin background - and in Islamic thinkers such as Avicenna or al-Ghazālī. More detailed information regarding this issue can be found in Nicola Polloni, "Gundissalinus and the Application of al-Fārābī’s Metaphysical Programme. A Case of 
Dominicus Gundissalinus was one of the most prominent translators in Toledo and his work was closer to the new ways of understanding philosophy that arose after the rediscovery of the Aristotelian material. This treatise leaves the mechanical arts out of the picture of philosophy describing it as humana scientia, whereas theology, understood as the science of revelation, is divina scientia. This is relevant because neither Hugh of Saint Victor nor Thierry of Chartres thought of them as of entirely separate fields of knowledge. The prologue of this work illuminates us on Gundissalinus's understanding of philosophy: "there is no knowledge which is not a part of philosophy." 29 And he adds that "the aim of philosophy is to understand the truth about everything that is, inasmuch as it is possible for men." 30

Gundissalinus divides philosophy mainly into theoretical (physica sive scientia naturalis; mathematica sive scientia disciplinalis; theologia sive prima philosophia sive metaphysica) and practical (politica, oeconomica, ethica). For the sake of our aim, we will focus on his understanding of physica sive scientia naturalis, which is the part of philosophy that studies things in matter which are subject to motion. ${ }^{31}$ And it is called natural because it only deals with natural things, whose main feature is motion. ${ }^{32}$ Physica is no longer the mere investigation of the causes of things, but rather the investigation of natural things as they are found in nature. Those natural things are defined by Gundissalinus in opposition to artificial beings, that is, those which are not made by men. ${ }^{33}$ Among natural things, he mentions simple bodies "such as herbs, fruits, stones and metals." ${ }^{34}$ What is also important for our purpose is that the Toledan translator includes the study of plants as a part of natural

Philosophical Transfer," Mediterranea. International Journal for the Transfer of Knowledge 1 (2016): 69-106.

29 "Nulla est scientia quae philosophiae non sit aliqua pars." Dominicus Gundissalinus, De divisione philosophiae, ed. Ludwig Baur (Münster: Aschendorff, 1903), prologue, 5, 17-18. There is a more recent edition of this text by Alexander Fidora and Dorothée Werner, Dominicus Gundissalinus, Über die Einteilung der Philosophie, (Freiburg: Herder, 2007). Given the availability of Baur's edition, we prefer to use its pagination. "Scientia" is a polysemic term, and even though it is systematically translated as science, here it should rather be understood as knowledge or area of knowledge.

30 "Intentio philosophiae est comprehendere veritatem omnium quae sunt, quantum possibile est homini." Dominicus Gundissalinus, De divisione, prologue, 9, 21-22.

31 "Scientia naturalis est scientia considerans sola inabstracta et cum motu." Ibid., 19, 15-16.

32 "Haec autem scientia physica, i.e. naturalis dicitur, quia de solis naturalibus, quae naturae motui subiacent, tractare intendit." Ibid., 27, 11. 15-17.

33 "Naturalia sunt quae motu naturae visibiliter operantis de potentia ad actum prodeunt." Ibid., 10, 17-18.

${ }^{34}$ Ibid., 86, 6-7. 
philosophy, and not only as related to medicine and agriculture. The study of plants corresponds to the seventh part of natural philosophy, and it comprises "the consideration of this, what the species of plants have in common and that which is proper to each of them, which is one of the two speculative parts of the things composed by diverse elements. This is taught in the De vegetabilibus." ${ }^{35}$

The understanding of natural philosophy and its content would still be subject to further changes, most of them taking place in the thirteenth century when Aristotelian philosophy and its natural focus came to be seen as something problematic. The first ban on Aristotelian philosophy would be issued already in 1210. This ban affected the natural works of Aristotle and the commentaries related to them. Yet the different bans and prohibitions would not prevent the shaping of an entirely new curriculum which would be Aristotelian in nature. This new program of studies, fully established in 1255 , would also include the Book on Plants, thought to be a work of Aristotle and thus pertaining to the larger corpus of those natural works that were banned at the early stages of the formation of the University of Paris.

\section{The New Curriculum in the Thirteenth Century: 1210-1255}

The early bans on Aristotelian philosophy serve as a testimony that these works were being read in Paris. Aristotelian works were banned several times starting from 1210, when the private or public reading of Aristotle's books and Aristotelian commentaries on natural philosophy were prohibited. ${ }^{36}$ The ban would be renewed in 1215. In 1231, Pope Gregory IX issued the bull Parens scientiarum in which the ban of 1215 was still at work, although there he claims that they would designate a commission to examine the books on natural philosophy in order to correct their errors. ${ }^{37}$ This commission would never convene due to the death of one of its appointed members, William of Auxerre. ${ }^{38}$ One of the main accusations to justify the examination

\footnotetext{
35 "Consideratio de eo, in quo communicant species vegetabilium, et de eo, quod est proprium cuiusque eorum; quae est una ex duabus partibus speculativis de compositis diversarum partium; et hoc docetur in libro De vegetabilibus." Ibid., 23, 6-9.

${ }_{36}$ "Nec libri Aristotelis de naturali philosophia nec commenta legantur Parisius publice vel secreto, et hoc sub pena excommunicationis inhibemus." Heinrich Denifle and Émile Chatelain, Chartularium Universitatis Parisiensis (Paris: A. Delalain, 1889), 70, n. 11.

${ }^{37}$ Ibid., 136, n. 79.

${ }^{38}$ See Stephen Brown, “The Intellectual Context of Later Medieval Philosophy: Universities, Aristotle, Arts, Theology," in Routledge History of Philosophy Volume III: Medieval Philosophy, ed. John Marenbon (New York: Routledge, 2004), 191.
} 
of these errors has to do with the profane novelties related to Aristotelian philosophy. ${ }^{39}$

There are two main tendencies regarding the effectiveness of the different bans and prohibitions. Some scholars state that they were valid de iure, but not de facto, that is, that Aristotelian works were legally prohibited but that the prohibition did not really apply. ${ }^{40}$ The other tendency suggests that this was not the case, since the newly established University of Toulouse (1229) advertised itself as defending the libertas scholastica or academic freedom and claimed that the works on natural philosophy which were banned in Paris could be freely studied there. ${ }^{41}$

In spite of the different bans and prohibitions, there is a document dating from ca. 1230-1240, a master's guide for the students of arts in Paris, which collects all of the Aristotelian works available as part of their education (MS Ripoll, 109ff. 134ra-158va). ${ }^{42}$ In this document, which follows the triple Aristotelian division of philosophy, the master divides philosophy into rational or theoretical, natural, and moral. The relevant areas for our purpose are the first and the second, so we will not deal here with the contents of moral philosophy. When it comes to rational or theoretical philosophy, this guide for students includes the trivium: for grammar, the books of Priscianus and Donatus's Barbarismus; for rhetoric, Cicero's De inventione; Porphyry's Isagoge, the Organon and the logical treatises of Boethius for dialectics. Natural philosophy includes metaphysics, mathematics, and physics. For metaphysics the standard texts are Aristotle's Metaphysics and the pseudoAristotelian Liber de causis. Under mathematics this master subsumes the subjects of the quadrivium, but assigns to some of its branches works that were unknown in the earlier Middle Ages. For astronomy, Ptolemy's Almagest; for geometry Euclid's Elements; for arithmetic Boethius's Institutio arith-

\footnotetext{
${ }^{39}$ A study of the different mentions of the new philosophy as a set of "profane" or "dangerous" novelties can be found in Luca M. Bianchi, "Prophanae novitates' et 'doctrinae peregrinae': la méfiance à l'égard des innovations théoriques aux XIII ${ }^{\mathrm{e}}$ et $\mathrm{XIV}^{\mathrm{e}}$ siècles," in Tradition, Innovation, Invention, ed. Hans-Joachim Schmidt (Berlin: de Gruyter, 2005), 211-29.

${ }^{40}$ See, for instance, John Marenbon, Medieval Philosophy. An Historical and Philosophical Introduction (New York: Routledge, 2010), 213.

${ }^{41}$ See Dod, "Aristoteles Latinus," 71.

${ }^{42}$ This text has been edited in Charles H. Lohr, "The Medieval Interpretation of Aristotle," in The Cambridge History of Later Medieval Philosophy, eds. Norman Kretzmann, Anthony Kenny, and Jan Pinborg (Cambridge: Cambridge University Press, 2008), 84-96. It can also be found in Claude Lafleur and Joanne Carrier, Le "Guide de l'étudiant parisien" d'un maître anonyme de la Faculté des arts de Paris au XIII siècle (Québec: Publications du Laboratoire de philosophie ancienne et médiévale de la Faculté de philosophie de l'Université Laval, 1992).
} 
metica, and for music Boethius's Institutio musica. Physics, or rather physica, being at a lower degree of abstraction than metaphysics and mathematics, is described as scientia naturalis inferior. This inferior knowledge of natural things contains all the works ascribed to Aristotle on natural philosophy: Physica, dealing with the general principles of change; De caelo, studying the eternal motion of celestial bodies; De generatione et corruptione, treating the four sublunary elements which explain generation and corruption; Meteora, which includes a great variety of natural phenomena; Aristotle's works on animals; De anima, Parva naturalia, De motu cordis, De sensu et sensato and the most important text for our aim, De plantis, thought to have been written by Aristotle but in fact a pseudo-Aristotelian treatise.

The most relevant feature of this division relies on the new organization of the different areas, which reflects a systematization of knowledge with natural philosophy as its foundation. This is also the case for moral philosophy, since men are natural beings who only as such operate in this world. At the same time, natural philosophy represents the increasingly more specialized areas of knowledge as well as the path towards theoretical philosophy. Furthermore, natural philosophy is also a part of theoretical philosophy, mainly as prima philosophia or metaphysics: this is the discipline that allows us to describe not only reality from a more theoretical perspective, but also the theoretical relations among the different areas of knowledge.

How the different classifications of the disciplines contributed to the understanding of knowledge in the late Middle Ages is very well exemplified by these words of Thomas Aquinas in Summa theologiae (1265-1274):

The different means through which knowledge is obtained introduce the different sciences. The astronomer and the natural philosopher demonstrate the same conclusion, - namely, that the Earth is round -, but the astronomer by means of mathematics, that is, abstracting from matter; the natural philosopher [demonstrates] by considering that which is related to matter. Hence, nothing forbids that, for these things which are discussed within the philosophical disciplines as knowable in light of natural reason, that other science discusses them as knowable in light of divine revelation. Whence, theology which pertains to sacred doctrine differs in kind from that theology which is a part of philosophy. ${ }^{43}$

\footnotetext{
43 "Diversa ratio cognoscibilis diversitatem scientiarum inducit. Eandem enim conclusionem demonstrat astrologus et naturalis, puta quod terra est rotunda, sed astrologus per medium mathematicum, idest a materia abstractum; naturalis autem per medium circa materiam consideratum. Unde nihil prohibet de eisdem rebus, de quibus philosophicae disciplinae tractant secundum quod sunt cognoscibilia lumine naturalis rationis, et aliam scientiam
} 
What we can infer from this is that each new perspective (subiectum formale) with which we investigate reality and its particularities (subiectum materiale) introduces a new science, a new discipline. In this way, we observe how the different branches of knowledge were increasingly and gradually perceived as specialized fields. Another important remark concerning the words of Thomas Aquinas has to do with the separation between philosophy and theology, which are now regarded as two different disciplines which contribute to each other to some extent. ${ }^{44}$

To get back to the chronological order of events following the reception of Aristotelian philosophy at the University of Paris, paradigm of philosophical and scientific education in the late Middle Ages, 1245 is the next important date. In this year, Pope Innocent IV extended the ban on the Aristotelian works to Toulouse. Only ten years later, in 1255, the University of Paris would approve its statute and establish the curriculum of the Faculty of Arts, which included all of the Aristotelian works together with their commentaries. The new educational program allotted five weeks to studying the Book on Plants. ${ }^{45}$ This is relevant if we recall that one of the most important treatises within this context, the Book on Causes (Liber de causis), was to be studied in only seven weeks. De plantis was widely copied in the Middle Ages, for which its 159 surviving manuscripts in Latin serve as a testimony. ${ }^{46}$ The Book on Plants played a foundational role in the understanding of botany as a more theoretical science. Let us, then, move on to explaining its reception, some further insights into its contents and its importance in the shaping of botany as a specialised discipline.

tractare secundum quod cognoscuntur lumine divinae revelationis. Unde theologia quae ad sacram doctrinam pertinet, differt secundum genus ab illa theologia quae pars philosophiae ponitur." Thomas Aquinas, "Summa Theologiae, Ia , q. 1, a.1, ad 2," in Corpus Thomisticum, accessed May 20, 2019, http://www.corpusthomisticum.org/sth1001.html.

${ }^{44}$ The relations between philosophy and theology in Thomas Aquinas exceed the scope of this paper and certainly are not a simple issue. For deeper insights into this question, see Mark D. Jordan, "Theology and Philosophy," in The Cambridge Companion to Aquinas, eds. Norman Kretzmann and Eleonore Stump (Cambridge: Cambridge University Press, 2006), 232-51.

45 "Statutum facultatis artium de modo docendi et regendi in artibus, deque libris qui legendi essent [...] librum de causis in septem septimanis; librum de sensu et sensato in sex septimanis; librum de sompno et vigilia in quinque septimanis; librum de plantis in quinque septimanis; librum de memoria et reminiscentia in duabus septimanis." Denifle and Chatelain, Chartularium Universitatis Parisiensis, 277-78.

${ }^{46}$ For a full list of the surviving manuscripts, see Nicolaus Damascenus, De plantis, 475-82. This text is so far the best source for the different versions and translations of the Book on Plants. 


\section{De plantis: Its Reception and Transmission in the Latin West}

First of all, and to avoid confusion, it should be underlined that the Book on Plants, Liber de plantis, is sometimes also referred to as Liber de vegetabilibus and as Liber Aristotelis de vegetabilibus et plantis. ${ }^{47}$ Whereas there are only five surviving manuscripts of this treatise in Arabic, a huge amount of them is still extant in Latin. We owe the translation from Arabic into Latin, composed in ca. 1200, to Alfredus Anglicus, also known as Alfred of Sareshel. The translation was very likely made in Spain, given the use of Spanish words such as acelga (chard) and belenum (henbane) and the Spanish way of transliterating Arabic words. ${ }^{48}$

There is one account of another translation, but it is only mentioned by Roger Bacon in his Quaestiones supra De plantis, a text that he used for teaching this book in Oxford. ${ }^{49}$ As for the aforementioned belenum, in Opus tertium Roger Bacon also complains about the choice of this word by the translator, saying "belenum is [a] Spanish [word] and no one in Paris or in England could by means of this translation know what belenum is." ${ }^{50}$ And he was not the only one to complain about the obscurity and difficulties of the translation, since Albert the Great would do the same in his huge work De vegetabilibus, where he says: "And this is Aristotle's teaching on the colors of the woods, which because of the bad quality of the translation is hardly intelligible." ${ }^{51}$ In any case, it was Thomas Aquinas who said that Aristotle was not the author of De plantis, but Theophrastus. ${ }^{52}$ The same happened with Peter of Auvergne, who said that Theophrastus completed the lack of

${ }^{47}$ As found in MS BNF 478, f. 42r from the Bibliothèque nationale de France.

${ }^{48}$ Nicolaus Damascenus, De plantis, 472-73. Note that in this source acelga is mistakenly translated as beetroot.

49 "Alia translatione dicit quod est composita, et per rationem patet." Roger Bacon, "Quaestiones supra de plantis," in Opera hactenus inedita Rogeri Baconi, ed. Robert Steele (Oxford: Clarendon Press, 1932), 218, 21-22.

50 "Belenum est Hispanicum, et nullus Parisius nec in Anglia potest per illam translationem scire quid est belenum." Roger Bacon, "Opus Tertium," in Fr. Rogeri Bacon Opera quadam hactenus inedita, ed. John S. Brewer (Cambridge: Cambridge University Press, 2012), 91.

51 "Et haec est scientia Aristotelis de coloribus lignorum, quae propter malitiam translationis vix est intelligibilis.” Albertus Magnus, De vegetabilibus libri VII, eds. Ernst H. F. Meyer and Karl F. W. Jessen. (Berlin: Georgii Reimeri, 1867), lib. IV, tract. IV cap. 1, 277, 137-38.

52 "In libro de plantis, quem Aristoteles non fecit, sed Theophrastus, ut Alexander hic dicit in commento." Thomas Aquinas, "Sententia libri De sensu et sensato, tract. 11.11 n. 14," in Corpus Thomisticum, accessed May 20, 2019, http://www.corpusthomisticum.org/css01.html. 
his master (i.e., Aristotle) by writing De plantis. ${ }^{53}$ It was much later, in the nineteenth century, that Ernst Meyer showed that the author was not Aristotle but Nicolaus of Damascus. ${ }^{54}$

De plantis should also be regarded as a special case if we consider its many versions and translations, since it was translated and re-translated several times. After the Latin translation from Arabic was made by Alfredus Anglicus, a retroversion from Latin into Greek was composed around 1300. This version, which would become the predominantly used translation - possibly in an attempt to recover the long lost treatise in its original language -, was translated back into Latin again twice in the sixteenth century, in 1542 and $1543 .{ }^{55}$ The Latin retroversion dating from 1542 would be included in the corpus of Averroes' commentaries on Aristotle in the editions of Venice, apud Iunctas, 1550-1562. The other one was composed by a certain Andrea a Lacuna, Secobiensi, Philiatro, interprete Coloniae. ${ }^{56}$

There is yet one other puzzling fact about the historical development of this relatively short text, which is the presence of comparatively very few commentaries written on it. Whereas there are 159 surviving manuscripts, there are only nine extant commentaries in Latin. ${ }^{57}$ Among those, only the ones made by Roger Bacon, Albert the Great, Peter of Auvergne, Adam of Bockenfield and Alfredus Anglicus, the translator of the original text, have been edited. ${ }^{58}$ The remaining ones are those of Vincent de Beauvais, in Speculum maius, Book IX, Speculum naturale; two other manuscripts dating from the late thirteenth or early fourteenth centuries (in the Bodleian manuscripts, Tanner 116 and Digby 17, respectively), possibly authored by

53 “Theoprastus defectum magistri sui complevit, quod librum de plantis composuit." Petrus de Alvernia, Sententia Super Librum De Vegetabilibus et Plantis, ed. Evert L. J. Poortman (Leiden: Brill, 2003), 4, 17-18.

${ }^{54}$ Nicolaus Damascenus, De plantis, 9-11.

${ }^{55}$ Ibid., 2-3.

${ }^{56}$ Sybil Douglas Wingate, The Mediaeval Latin Versions of the Aristotelian Scientific Corpus, with Special Reference to the Biological Works (Dubuque, IA: W. C. Brown Reprint Library, 1963), 61.

${ }^{57}$ Raymond James Long, "Botany," in Medieval Latin. An Introduction and Bibliographical Guide, eds. Frank A. C. Mantello and Arthur G. Rigg (Washington, DC: Catholic University of America Press, 1999), 404.

${ }^{58}$ Adam of Bockenfield, Glossae super De vegetabilibus et plantis, ed. Raymond James Long (Leiden: Brills, 2013); Alfred of Sareshel, "Super librum De vegetabilibus," in Medieval Studies 47 (1985): $125-67$. There is also a $15^{\text {th }}$-century Venice manuscript whose author seems to have been Joannes Cronisbenus, about whom nothing else is known. 
Simon de Faversham. Sybil Douglas Wingate also mentions the existence of one other manuscript in Paris. ${ }^{59}$

\section{Importance and Relevance of De plantis}

In order to understand the impact of De plantis, we should keep in mind the distinction between subjectum materiale and subiectum formale that has been mentioned earlier when relating the words of Thomas Aquinas. The subiectum formale is the perspective of each science when studying reality. The subjectum materiale is the subject matter of a science. That which appears with De plantis is a theoretical way of approaching botanical studies, as opposed to the more practical way contained in herbal books and also related to the uses of plants for medicine, pharmacy and agriculture.

The introduction of Aristotle's Physica and De anima into the medieval Latin West is essential for understanding the foundations of this theoretical approach. Physica contributes to spreading the idea that natural beings are those capable of motion or subject to motion. Insomuch as plants pertain to this kind, they constitute a part of natural philosophy. What changes here is the way of studying them, which is where De anima comes into place: plants are capable of motion by themselves and, what is more, they represent the basic principles of life. Averroes, whose commentaries were used as a guide to understand Aristotle's philosophy in the Middle Ages, makes the following remarks about the issue in the Long Commentary on the De anima of Aristotle: "I understand by life the principle which is common to everything alive, namely, to be nourished, to grow and to suffer diminution in an essential way. This is characteristic of plants." ${ }^{\prime 0}$ And Aristotle himself says:

We take, then, as our starting point for discussion that it is life which distinguishes the animate from the inanimate. But the term life is used in various senses; and, if life is present in but a single one of these senses, we speak of a thing as living. Thus, there is intellect, sensation, motion from place to place and rest, the motion concerned with nutrition and further, decay and growth. Hence it is that all plants are supposed to have life. Apparently, they have within themselves a faculty and principle whereby they grow and decay in opposite directions. For plants do not grow upwards without growing downwards; they

\footnotetext{
${ }^{59}$ For the other extant MSS. I rely on the words of Douglas Wingate, Mediaeval Latin Versions, $68-69$.

${ }^{60}$ Averroes [Ibn Rushd] of Córdoba. Long Commentary on the De Anima of Aristotle (New Haven: Yale University Press, 2009).
} 
grow in both directions equally, in fact in all directions, as long as they are constantly nourished and therefore continue to live, so long as they are capable of absorbing nutriment. ${ }^{61}$

Since we have already mentioned the most important contents of $D e$ plantis, our references to it will be limited to those issues which are relevant to our purpose within this section. The first thing that we should recall in this regard is that the Book on Plants consists of two quite distinct parts. The first one sets the theoretical framework for the study of plants. The main questions pertaining to this part are what it is to be alive for a plant and whether plants sense and desire things, and even if they breathe or sleep. The text also explores the processes of nutrition, growth and the mixture of the sexes in plants, that is, reproduction, and whether they properly have a sex or not. This first part also examines parts of plants and the differences between plants while trying to provide an answer to biodiversity, which is to be found mainly in geographical and climatological differences. In sum, one of the main attempts of this treatise is to try to provide an answer to what the life functions that we can observe in plants are, as opposed to those which can be seen in animals. In the Aristotelian understanding of philosophy, the observational element is what brings proper knowledge, which cannot be constructed independently of the senses, as expressed by the famous scholastic motto nihil est in intellectu quod prius non fuerit in sensu, that is, there is nothing in the intellect which was not previously in the senses.

The second part of the treatise has to do with the generation of plants and their accidents, which also includes grafting, i.e., combining plants to create new species. This shows an understanding of nature as something that can be transformed by modification. The agricultural element is no doubt present here, but what makes the difference is that the instructions for grafting are based on observation, such as that it is easier to combine plants that are similar. Another important feature of this treatise is that it includes a very basic experiment to prove that salt water is heavier than fresh water by using an egg. Traditionally seen as part of a more "modern" way of understanding of science, these aspects are also present in this widely copied text.

${ }^{61}$ Aristotle, De Anima with Translation, Introduction, and Notes, trans. and ed. Robert D. Hicks (Cambridge: Cambridge University Press, 1907), 2.2.413a21-31. 


\section{Conclusion}

Throughout this paper we have explored the ways in which the reception of Aristotelian philosophy helped to provide the medieval Latin West with a new understanding of science. In this regard, the paper underscored the impact of the Book on Plants and its special historical development: translated, re-translated; widely copied, at least in the Latin West, but lacking a proper commentary tradition. These features make this treatise very unique in the Middle Ages.

The Book on Plants inaugurated the theoretical tradition of botany, which, in consonance with the Aristotelian perspective, deepens its roots in empirical observation. This is the time when we first observe a bifurcation in botanical studies which would extend throughout the Middle Ages ${ }^{62}$ Whilst the more practical tradition has to do with the arts and the application of plants for medicine, pharmacy and agriculture, the Book on Plants represents a completely different approach, theoretical in nature. Evidence for this bifurcation in the botanical tradition can also be seen in the fact that herbal books, such as Dioscorides' were virtually unknown outside monastic collections and not included in the university curriculum. On the other hand, this pseudo-Aristotelian treatise can be found almost exclusively in university collections. ${ }^{63}$

The far-reaching echoes of the Book on Plants in the Renaissance and beyond have to be left out of the scope of this paper, since they exceed the permitted space. Let us hope that our contribution has enabled us to shed light on this largely neglected subject in the fields of medieval philosophy and history of medieval science. We also expect to have added to the muchneeded discussion related to how philosophy, in its being the mother of the sciences, was responsible for the making of each of the fields emerging from it independent disciplines. Nevertheless, they still return to philosophy when seeking their foundations.

\section{Bibliography:}

Adam of Bockenfield. Glossae super De vegetabilibus et plantis. Ed. Raymond James Long. Leiden: Brills, 2013.

${ }^{62}$ Long, "Botany," 403.

${ }^{63}$ Ibid. 
Albertus Magnus. De vegetabilibus Libri VII. Eds. Ernst H. F. Meyer and Karl F. W. Jessen. Berlin: Georgii Reimeri, 1867.

Alfred of Sareshel. "Super librum de vegetabilibus." Medieval Studies 47 (1985): 125-67.

Arberry, Arthur J. "An Early Translation from the Greek." [= De plantis, first edition of the Arabic text] Bulletin of the Faculty of Arts of the Cairo University 1 (1933): 48-76.

Aristotle. De Anima with Translation, Introduction, and Notes. Trans. and ed. Robert D. Hicks. Cambridge: Cambridge University Press, 1907.

Averroes [Ibn Rushd] of Córdoba. Long Commentary on the De Anima of Aristotle. New Haven: Yale University Press, 2009.

Badawi, Abdarrahman. Aristutalis fi-n-nafs. Cairo: Maktabat al-Nahḍah alMisriyyah, 1954.

Bar-On, Yinon M., Rob Phillips, and Ron Milo, "The Biomass Distribution on Earth." PNAS 115, no. 25, (2018): 6506-11. https://doi.org/10.1073/pnas.1711842115.

Bianchi, Luca M. “Prophanae novitates' et 'doctrinae peregrinae': la méfiance à l'égard des innovations théoriques aux XIII et XIV siècles." In Tradition, Innovation, Invention, ed. Hans-Joachim Schmidt, 211-229. Berlin: de Gruyter, 2005.

Bouyges, Maurice. "Sur le de Plantis d' Aristote-Nicolas à propos d'un manuscrit arabe de Constantinople." Mélanges de L'Université Saint-Joseph Beyrouth 9, no. 2 (1923): 71-89.

Brown, Stephen. "The Intellectual Context of Later Medieval Philosophy: Universities, Aristotle, Arts, Theology." In Routledge History of Philosophy Volume III: Medieval Philosophy, ed. John Marenbon, 188-203. London: Routledge, 2004.

Denifle, Heinrich, and Émile Chatelain. Chartularium Universitatis Parisiensis, Vol. 1. Paris: A. Delalain, 1889. https://doi.org/10.1017/CBO9781107338500.002.

Diamond, Jared M. Guns, Germs, and Steel: The Fates of Human Societies. New York: Norton, 2005.

Dod, Bernard G. "Aristoteles latinus." In The Cambridge History of Later Medieval Philosophy, eds. Norman Kretzmann, Anthony Kenny, and Jan Pinborg, 45-79. Cambridge: Cambridge University Press, 2008. 
Dominicus Gundissalinus. De divisione philosophiae. Ed. Ludwig Baur. Münster: Aschendorff, 1903.

Douglas Wingate, Sybil. The Mediaeval Latin Versions of the Aristotelian Scientific Corpus, with Special Reference to the Biological Works. Dubuque, IA: W. C. Brown Reprint Library, 1963.

Hardy, Frederick Gavin, and Laurence M. V. Totelin. Ancient Botany. New York: Routledge, 2016.

Hugo Sancti Victoris. "Didascalicon." In Documenta Catholica Omnia. Accessed May 20, 2019. http://www.documentacatholicaomnia.eu/04z/z_1096-1141__Hugo_ De_S_Victore__Didascalicon__LT.pdf.html.

Ibrahim Bayyumi Madkur, Ibn Sina al-Šifa, al-Ṭabiiyyat. Cairo: Dar al-Katib al-Arabi li-al-Tibaa wa-al-Našr, 1969.

Jordan, Mark D. "Theology and Philosophy." In The Cambridge Companion to Aquinas, eds. Norman Kretzmann and Eleonore Stump, 232-51. Cambridge: Cambridge University Press, 2006. https://doi.org/10.1017/CCOL0521431956.010.

Lafleur, Claude, and Joanne Carrier. Le "Guide de l'étudiant parisien" d'un maître anonyme de la Faculté des arts de Paris au XIII siècle. Québec: Publications du Laboratoire de philosophie ancienne et médiévale de la Faculté de philosophie de l'Université Laval, 1992.

Liddell, Henry G., and Robert Scott. Greek-English Lexicon. New York: Harper \& Brothers, 1883.

Lohr, Charles H., "The Medieval Interpretation of Aristotle." In The Cambridge History of Later Medieval Philosophy, eds. Norman Kretzmann, Anthony Kenny, and Jan Pinborg, 80-98. Cambridge: Cambridge University Press, 2008.

Long, Raymond James. “Botany." In Medieval Latin. An Introduction and Bibliographical Guide, eds. Frank A. C. Mantello and Arthur G. Rigg, 401-5. Washington, DC: Catholic University of America Press, 1999.

Marenbon, John. Medieval Philosophy. An Historical and Philosophical Introduction. New York: Routledge, 2010.

Nicolaus Damascenus. De plantis. Five Translations. Eds. Hendrik J. Drossaart Lulofs and Evert L. J. Poortman. Amsterdam: North-Holland Publishing, 1989.

Petrus de Alvernia. Sententia Super Librum De Vegetabilibus et Plantis.

Ed. Evert L. J. Poortman. Leiden: Brill, 2003. 
Polloni, Nicola. "Gundissalinus and the Application of al-Fārābī’s Metaphysical Programme. A Case of Philosophical Transfer." Mediterranea. International Journal for the Transfer of Knowledge 1 (2016): 69-106. https://doi.org/10.1017/ CCOL0521431956.010.

Roger Bacon. “Opus Tertium." In Fr. Rogeri Bacon Opera quodam hactenus inedita, ed. John S. Brewer. Cambridge: Cambridge University Press, 2012.

Roger Bacon. "Quaestiones supra De plantis." In Opera hactenus inedita Rogeri Baconi. Ed. Robert Steele. Oxford: Clarendon Press, 1932.

Taylor, Jerome. The Didascalicon of Hugh of Saint Victor. New York: Columbia University Press, 1961.

Thomas Aquinas. "Sentencia libri De sensu et sensato, tract. 11. 11 n. 14." In Corpus Thomisticum. Accessed May 20, 2019. http://www.corpusthomisticum.org/css01. html.

Thomas Aquinas. "Summa Theologiae, Ia, q. 1, a.1, ad 2." In Corpus Thomisticum. Accessed May 20, 2019. http://www.corpusthomisticum.org/sth1001.html.

Yavuz, Mustafa, and Özlem Korkmaz. "Botánica en al-Ándalus: un estudio comparativo de trabajos ilustrados de botánica en el Magreb y Máshreq." Awraq, no. 17-18 (2017): 169-86.

Catalogue of Life. Accessed May 30, 2019. http://www.catalogueoflife.org/col/ browse/tree?befbfbb8a465d5f008cb605a3037ae63. 